\title{
Genetic Diversity and Fine-Scale Genetic Structure in Syagrus oleracea (Mart.) Becc.: A Survivor Palm Species of the Semiarid
}

\author{
Luciana Rodrigues de Souza ${ }^{1}$, Helbert Fagundes Soares ${ }^{1}$, Sara Luiza Ramos Ribeiro ${ }^{1}$, \\ Afrânio Farias de Melo Junior ${ }^{1}$, Murilo Malveira Brandão ${ }^{1}$, Elytania Veiga Menezes ${ }^{1}$, \\ Vanessa de Andrade Royo ${ }^{1} \&$ Dario Alves Oliveira ${ }^{1}$ \\ ${ }^{1}$ Laboratory Bioprospecting and Genetic Resources and Laboratory of Natural Products, State University of \\ Montes Claros, Campus Darcy Ribeiro, Vila Mauriceia, Montes Claros, MG, Brazil \\ Correspondence: Vanessa de Andrade Royo, Laboratory Bioprospecting and Genetic Resources and Laboratory \\ of Natural Products, State University of Montes Claros, Campus Darcy Ribeiro, Vila Mauriceia, CEP 39401-089, \\ Montes Claros, MG, Brazil. Tel: 55-383-229-8342. E-mail: vanroyo31@gmail.com
}

Received: February 24, 2019 Accepted: March 25, 2019 Online Published: May 15, 2019

doi:10.5539/jas.v11n6p373 URL: https://doi.org/10.5539/jas.v11n6p373

\begin{abstract}
The species Syagrus oleracea is a native palm tree, present in highly impacted environments of the Brazilian semiarid. This species is exploited for use in the manufacture of folk crafts and for human and animal feeding. The objective of this study was to characterize the diversity and genetic structure of individuals from different populations, located in anthropic regions of the Brazilian semiarid region, in the state of Minas Gerais. This information is important for species management and conservation strategies. Thus, we used ISSR molecular markers in 157 individuals in seven populations of $S$. oleracea. Looking at the results, one can observe that amplifications of 109 locos occurred and that an average of 18, 17 alleles were found on each primer, values that demonstrated that the ISSR technique used was highly efficient. The genetic diversity indexes were observed, showing expected heterozygosity (He) and Shannon index (I) of 0.260 and 0.383 , respectively. The number of alleles observed (na) among populations was 1.954 and the effective number of alleles (ne) was 1,606. Individuals of the populations are genetically structured in groups (demes) in a random and aggregate manner. We obtained the amplification of 109 ISSR loci, with a mean of 18.2 alleles per primer. The genetic diversity indexes revealed expected heterozygosity (He) and Shannon index (I) of 0.260 and 0.383 , respectively. The number of alleles observed (na) was 1.954 and the effective number of alleles (ne) was 1.606. The value of the indirect gene flow found was 1.546. Evidence of high levels of kinship in populations was found, possibly due to low migration rates and geographical barrier. In addition, we observed signs of overexploitation in the areas, which consequently leads to a low rate of gene flow, occurring inbreeding among the sampled populations of Syagrus oleracea.
\end{abstract}

Keywords: arecaceae, ISSR, genetic variability, spatial genetic structure

\section{Introduction}

The species Syagrus oleracea (popularly known as guariroba and catolé) is a palm tree of the family Arecaceae, native to Brazil, of a long size that can reach more than $20 \mathrm{~m}$ in height, a olitary trunk, they maintain their leaves throughout the year organized as a spiral and a little arched (Lorenzi et al., 2004). It has an abundance of fruits, presents on average 70 fruits, which germinate generally in 2-3 months (Lorenzi et al., 2004). The fruits have fibrous pulp, the almonds are solid, hard, white in color and quite oily (Santelli, 2006). S. oleracea, like most palm species, often has low percentages of germination, loses viability when they become dehydrated and thereby reduce germination (Martins et al., 1999).

The palm heart with bitter flavor is one of the characteristics of this species. The peroxidase and polyphenoloxidase enzymes act on the phenolic compounds (Shimokomaki et al., 1975), and render the pH value of palmitic acid (around 5.7) (Carneiro et al., 2003). The palm heart of the species becomes a delicacy, valuable and has great acceptance among the consumers (Jaime et al., 2007).

The S. orelarea palm is found in the states of São Paulo, Minas Gerais, Mato Grosso, Goiás, Mato Grosso do Sul and Bahia (Lorenzi, 1992). Although most palm trees are not yet considered endangered species, the disordered 
use by human action such as fragmentation decreases both the amount of subpopulation elements and pollinators, which consequently reduces the range of gene flow between subpopulations making them vulnerable.

Therefore, knowing the distribution patterns of genetic variation within and between natural populations is necessary for the establishment of conservationist and sustainable use practices (Frankel, 1983). The molecular markers are widely used to describe patterns of genetic variability in natural plant populations. These tools make it possible to detect variations in the genome at any stage of plant development (Kamada et al., 2009).

The Inter Simple Sequence Repeats (ISSR) molecular markers stand out in genetic analyzes, make it possible to verify intra and intertaxonomic variability in phylogenetic reconstructions, at species levels or above, and also through the molecular markers make it possible to obtain high degree of polymorphism, reproducibility and because they are considered low cost (Salimath et al., 1995).

In this context, the objective of this study was to characterize the genetic diversity, spatial genetic structure of Syagrus oleracea by ISSR molecular markers in natural populations of the Brazilian semiarid.

\section{Method}

\subsection{Study Area}

Samples were obtained from populations located in northern Minas Gerais-Brazil (Table 1).

Table 1. Sampling of S. oleracea populations and characterization of the areas

\begin{tabular}{|c|c|c|c|c|c|}
\hline Place & $\begin{array}{l}\mathrm{N}^{\circ} \text { of } \\
\text { Individuals }\end{array}$ & Latitude (S) & Longitude (W) & Altitude (m) & Conservation state \\
\hline Japonvar & 27 & $16^{\circ} 01^{\prime} 47.93^{\prime \prime}$ & $44^{\circ} 21^{\prime} 56.71^{\prime \prime}$ & 740 & $\begin{array}{l}\text { Little conserved area, with great number of Syagrus } \\
\text { oleracea and country region, with pasture. }\end{array}$ \\
\hline Josenópolis & 27 & $16^{\circ} 36^{\prime} 09.57^{\prime \prime}$ & $42^{\circ} 32^{\prime} 59.47^{\prime \prime}$ & 641 & $\begin{array}{l}\text { Area with large number of Syagrus oleraceae region } \\
\text { with presence of cattle and deforestation. }\end{array}$ \\
\hline Mirabela & 26 & $16^{\circ} 07^{\prime} 42.16^{\prime \prime}$ & $44^{\circ} 13^{\prime} 11.80^{\prime \prime}$ & 815 & $\begin{array}{l}\text { Area with large number of Syagrus oleracea, little } \\
\text { conserved region. }\end{array}$ \\
\hline Novorizonte & 19 & $16^{\circ} 00^{\prime} 04.33^{\prime \prime}$ & $42^{\circ} 26^{\prime} 14.54^{\prime \prime}$ & 906 & $\begin{array}{l}\text { More conserved area than the others, however, with } \\
\text { presence of housing, livestock and deforestation. }\end{array}$ \\
\hline Rio Pardo de Minas & 27 & $15^{\circ} 31^{\prime} 28.10^{\prime \prime}$ & $42^{\circ} 31^{\prime} 55.71^{\prime \prime}$ & 915 & $\begin{array}{l}\text { Less conserved area with presence of extractivism, } \\
\text { livestock and fires. }\end{array}$ \\
\hline São João da Ponte & 16 & $15^{\circ} 51^{\prime} 33.85^{\prime \prime}$ & $43^{\circ} 58^{\prime} 22.80^{\prime \prime}$ & 770 & $\begin{array}{l}\text { Area with few Syagrus oleracea, with pasture and } \\
\text { roadside. }\end{array}$ \\
\hline Varzelândia & 15 & $15^{\circ} 41^{\prime} 09.26^{\prime \prime}$ & $43^{\circ} 59^{\prime} 28.10^{\prime \prime}$ & 746 & $\begin{array}{l}\text { Area with few Syagrus oleracea, dirty field region at } \\
\text { the edge of highway. }\end{array}$ \\
\hline
\end{tabular}

\subsection{Molecular Analysis}

Leaves and roots of adult plants were collected from 157 individuals sampled in seven populations of Syagrus oleracea. UTM coordinates with Global Positioning System (GPS) mapped the individuals of S. oleracea.

The CTAB (cetyl trimethyl ammonium bromide) protocol proposed by Doyle and Doyle (1987) was used to extract the DNA from the leaves of each sample.

DNA amplification (PCR) was performed for each individual, with standard dilution of $1 \mu$ l of extracted DNA to $100 \mu \mathrm{l}$ ultrapure water $(1: 100)$. We tested 12 different universal ISSR primers described by Demesure et al. (1995). Amplification reactions were performed in a Veriti 96 Well Thermal Cycler Applied Biosystems thermocycler. The PCR reation was: $2.5 \mu \mathrm{L}$ diluted DNA, $6.0 \mu \mathrm{L}$ PCR buffer $(500 \mathrm{mM} \mathrm{KCl}, 100 \mathrm{mM}$ Tris-HCl $\mathrm{pH} 8.4,1 \%$ Triton X-100), $1.0 \mu \mathrm{L}$ of $\mathrm{MgCl}_{2}(50 \mathrm{mM}), 1.5 \mu \mathrm{L}$ of dNTP mix $(2.5 \mathrm{mM}), 1.5 \mu \mathrm{L}$ of primer ISSR 2.0 $\mu \mathrm{M}, 0.5 \mu \mathrm{L}$ of Taq polymerase (Phoneutria) at $5 \mathrm{U} / \mu \mathrm{L}$. The PCR reactions followed: prior denaturation at $94{ }^{\circ} \mathrm{C}$ for 2 minutes, 37 cycles of 30 seconds at $94{ }^{\circ} \mathrm{C}, 45$ seconds for primer annealing with annealing temperatures (Tm) ranging from $48.5-56{ }^{\circ} \mathrm{C}$ (Table 2), 1 minute and 30 seconds at $72{ }^{\circ} \mathrm{C}$ for the extension, ending with 40 minutes at $72{ }^{\circ} \mathrm{C}$ for final extension.

After PCR, the total volume of each sample was applied on agarose gel (1.5\%), stained with ethidium bromide $(0.02 \mu \mathrm{g} / \mathrm{ml})$, submerged in TBE buffer (90 mM Tris-Borate, $1 \mathrm{mM}$ EDTA).

The size of the amplified fragments was estimated by comparison with a molecular marker of 100 bp (DNA Ladder). Electrophoretic separation was performed for 3 hours at 100 volts. At the end of the run, the gels were visualized in transilluminator and photodocumented. 
Subsequently, the fragments were visualized and characterized according to the presence (1) or absence (0) of the fragments. Only fragments with high intensity were considered, and fragments with low reproducibility were discarded from the analyzes. A binary matrix was constructed for analyzes of diversity and genetic structure.

\subsection{Analysis of the Data}

Analysis of the genetic diversity of the populations was performed using the software POPGENE, V. 1.31 (Yeh, Yang, \& Boyle, 1999). The number of alleles observed (na), the effective number of alleles (ne) (Kimura \& Crow, 1964), the expected heterozygosity (He) (Nei, 1973), the Shannon index (I) (Lewontin, 1972), the polymorphic loci $(\mathrm{P})$ and the percentage of polymorphic loci $(\mathrm{P} \%)$.

We calculated the value of PIC (Polymorphic Information Content) that classifies the primers according to the polymorphism detection efficiency, in which values greater than 0.5 are considered quite informative, values between 0.25 and 0.50 are highly informative and lower values to 0.25 little informative (Botstein et al., 1980).

The distributions of genetic diversity among and within populations were evaluated by total heterozygosity (Ht), heterozygosity within the populations (Hs), population differentiation coefficient $\mathrm{G}_{\mathrm{ST}}$ (NEI, 1973) and gene flow $(\mathrm{Nm})$ estimated by formula $\mathrm{Nm}=0.25\left(1-\mathrm{G}_{\mathrm{ST}}\right) / \mathrm{G}_{\mathrm{ST}}$ (McDermott \& McDonald, 1993).

For analysis of significance of the components of the variance 1,000 permutations were tested. To test the correlation between genetic identity and geographic distance between populations, the genetic identity and genetic distance estimation of Nei (1978) among the populations of S. oleracea was carried out.

The genetic similarity was also calculated by the Jaccard similarity coefficient with the use of the NTSYS software (Rohlf, 2000), in which an UPGMA grouping (unweighted pair group method with arithmetic mean) was generated.

The analysis of the fine-scale genetic structure within each population was estimated with the value of coancestria using the kinship coefficient between the pairs of individuals for the distance classes (Hardy, 2003). We used the program Spagedi, version 1.2 (Hardy \& Vekemans, 2002), in the estimations of coefficient of kinship as coefficient consideration equals zero for inbreeding. For half-time jackknife re-sampling, confidence intervals were constructed based on the standard error of the mean of the estimates obtained. The confidence intervals have a $95 \%$ probability of the average co-estimate coefficient estimated for each distance class (Hardy \& Vekemans, 2002).

\section{Results and Discussion}

\subsection{Genetic Diversity}

The amplification of the six selected ISSR primers revealed 109 fragments, which ranged from 14 to 22 per primer and average of 18 fragments. The mean value of PIC for all primers was 0.344 , with a highest value found of 0.377 and the lowest value of 0.292 . The sizes of the fragments obtained ranged from 200 to 2300 nucleotide pairs. The results showed that the six primers used were efficient for the detection of polymorphism in the populations of Syagrus oleracea (Table 2).

In addition, the results revealed high polymorphism in all $S$. oleracea populations sampled in the different studied areas. Rossi et al. (2014) found a similar result (78.3\%) in the species Mauritia flexuosa (Arecaceae). Santos (2017) studied the species Copernicia prunifera (Arecaceae), found polymorphism of $99.09 \%$.

Table 2. ISSR primers, number of amplified fragments/primer (n), annealing temperature (Tm) and polymorphic information content (PIC) for Syagrus oleracea species

\begin{tabular}{lllll}
\hline Primer & Sequence (5'-3') & $\mathrm{n}$ & $\mathrm{Tm}\left({ }^{\circ} \mathrm{C}\right)$ & PIC \\
\hline UBC 826 AC8C & 5'-ACACACACACACACACC-3' & 20 & 51 & 0.330 \\
UBC 827 AC8G & 5'-ACA CAC ACA CAC ACA CG-3' & 17 & 51 & 0.397 \\
UBC 835 AG8YC & 5'-AGA GAG AGA GAG AGA GYC-3' & 14 & 48.5 & 0.292 \\
UBC 841 GA8YC & 5'-GAG AGA GAG AGA GAG AYC-3' & 19 & 49.5 & 0.326 \\
UBC 855 AC8YT & 5'-ACA CAC ACA CAC ACA CYT-3' & 17 & 56 & 0.341 \\
UBC 857 AC8YG & 5'-ACA CAC ACA CAC ACA CYG-3' & 22 & 50 & 0.380 \\
Total amplified fragments & & & 109 \\
\hline Mean
\end{tabular}


The heterozygosity is one of the most important and most used methods to estimate genetic variability (Brown et al., 2007). It is also considered the least sensitive method to variations in sample size when compared to other measures. The average heterozygosity values expected for entomophilous cross-pollinating species is 0.167 , widely dispersed species of 0.202 , tropical with 0.148 and arboreal species of 0.177 (Hamrick \& Godt, 1990). The values found for $S$. oleracea are in agreement with these authors, being considered above the average of these.

The number of alleles observed (na) among populations was 1.954, the effective number of alleles (ne) 1.606, showing no significant differences. Similar results were observed in a study developed by Vieira et al. (2015) with the species Copernicia prunifera, in which the number of alleles observed (na) 2.00 and effective alleles (ne) 1.46 were obtained.

It can be observed that in all populations the values obtained are in agreement with the average expected by the indexes indicated, and also it is found against a large part of the literature searched for palm trees with ISSR markers. The results in this study indicate the occurrence of genetic diversity, although apparently there are factors that lead to endogamy in the populations studied.

\subsection{Genetic Structure}

The genetic diversity based on the Hardy-Weinberg equilibrium observed among the populations was 0.244. The total heterozygosity $(\mathrm{Ht})$ value among the populations was 0.345 , the heterozygosity within the populations (Hs) of 0.260 and the gene flow $(\mathrm{Nm})$ obtained between the populations was 1.546 (Table 3 ).

Table 3. Distribution of genetic diversity in Syagrus oleracea: number of individuals (n); total heterozygosity $(\mathrm{Ht})$; heterozygosity within populations (Hs); divergence between populations $\left(\mathrm{G}_{\mathrm{ST}}\right)$; gene flow (Nm); polymorphic loci $(\mathrm{P})$; percentage of polymorphic loci $(\mathrm{P} \%)$

\begin{tabular}{llllllll}
\hline Population & $\mathrm{n}$ & $\mathrm{H}_{\mathrm{t}}$ & $\mathrm{H}_{\mathrm{s}}$ & $\mathrm{G}_{\mathrm{ST}}$ & $\mathrm{Nm}$ & $\mathrm{P}$ & $\mathrm{P} \%$ \\
\hline All & 157 & 0.345 & 0.260 & 0.244 & 1.546 & 104 & $95.41 \%$ \\
\hline
\end{tabular}

In most cases, allogamous species present higher values of genetic diversity within populations, in relation to autogamous species ( $\mathrm{Hu}$ et al., 2010). What was evidenced in this study, the found value of the population differentiation coefficient $\left(\mathrm{G}_{\mathrm{ST}}\right) 0.244$ and the heterozygosity within the populations $(\mathrm{Hs}) 0.260$, showed that the genetic divergence value among the populations is lower, than the value within populations. According to Hamrick (1991), factors such as geographic barriers, ecological differences and historical processes, and the dispersal capacity of species are determinant in the population genetic structure of a species. In addition, in tree species, when populations become isolated, they cause changes in basic evolutionary processes, such as genetic drift, selection, migration and breeding system, resulting in changes in genetic diversity (Silva, 2014).

It was observed in the populations of $S$. oleracea estimated gene flow $(\mathrm{Nm})$ of 1.546 . The value found indicates low gene flow, possibly due to low seed dispersion efficiency, or the existence of a geographical barrier between the populations considered in this study. The genetic identity values of Nei (1978) among the populations studied ranged from 0.791 in Rio Pardo de Minas and Mirabela to 0.941 in Novo Horizonte and São João da Ponte. It was observed lower values in the analyzes of genetic distance estimation in Novorizonte and São João da Ponte with a value of 0.06 and the highest value in Rio Pardo de Minas and Mirabela with a value of 0.234 (Table 5).

The dendrogram generated from the genetic identity matrix allowed the observation of all populations surveyed (Figure 1), showing a range of similarity among populations from $83 \%$ to $95 \%$. Retrating more than $87 \%$ of similarity. By the analysis of the dendrogram, we can notice the formation of two large groups: a group formed by the population of Rio Pardo de Minas and another composed by the other populations: Novorizonte, São João da Ponte, Varzelândia, Josenópolis, Japonvar and Mirabela. In addition, genetic differentiation was observed among populations, and some clusters could be visualized, that is, that there are genetic material exchanges. The results also demonstrate that some populations may require conservation strategies because they have lower genetic diversity values. Reis et al. (2017) evaluated the genetic diversity of 130 macaw palm (Acrocomia aculeata) individuals in 35 municipalities of Goiás, and verified the formation of five groups through the dendrogram, indicating that the municipalities that constitute junctions are similar to each other.

The values of Nei identity obtained showed a high degree of genetic similarity among the populations of $S$. oleracea studied (close to 1). The genetic structuring populations may be associated with geographic isolation 
and historical factors such as extinction events, recolonization, population size reduction that may leave genetic signals in the next generations (Hewitt, 1996; Schaal et al., 2003).

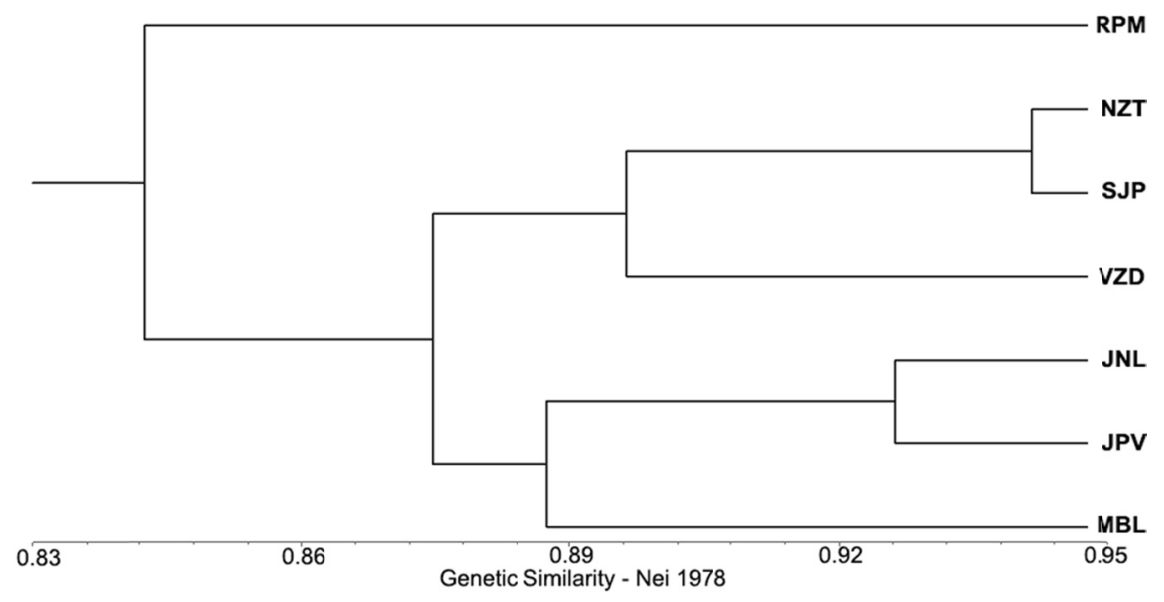

Figure 1. Dendrogram of genetic similarity populations of Syagrus oleracea, generated by UPGMA cluster. Data were sampled in the municipalities of Josenópolis (JNL), Japonvar (JPV), Mirabela (MBL), Novorizonte (NZT),

Rio Pardo de Minas), São João da Ponte (SJP) and Varzelândia (VZD)

Table 5. Estimates of Genetic Identity of Nei (1978) (above diagonal) and genetic distance (below diagonal) among the populations of Siagrus oleracea. Population: Josenópolis (JNL), Japonvar (JPV), Mirabela (MBL), Novorizonte (NZT), Rio Pardo de Minas (RPM), São João da Ponte (SJP) and Varzelândia (VZD)

\begin{tabular}{llllllll}
\hline Population & RPM & NZT & SJP & VZD & JNL & JPV & MBL \\
\hline RPM & - & 0.858 & 0.856 & 0.837 & 0.873 & 0.840 & 0.791 \\
NZT & 0.153 & - & 0.941 & 0.882 & 0.881 & 0.870 & 0.830 \\
SJP & 0.156 & 0.060 & - & 0.911 & 0.901 & 0.883 & 0.851 \\
VZD & 0.178 & 0.126 & 0.094 & - & 0.898 & 0.891 & 0.867 \\
JNL & 0.136 & 0.127 & 0.105 & 0.108 & - & 0.926 & 0.878 \\
JPV & 0.175 & 0.140 & 0.124 & 0.115 & 0.077 & - & 0.896 \\
MBL & 0.234 & 0.186 & 0.161 & 0.143 & 0.130 & 0.109 & - \\
\hline
\end{tabular}

\subsection{Spatial Genetic Structure}

The location of the areas and points with the presence of individuals of Syagrus oleracea sampled can be observed through images obtained by Google EarthTM (Figure 2). The determination of the spatial distribution of the genotypes was performed by obtaining the kinship coefficient (Hardy, 2003) among the individuals sampled for each distance class of the studied populations (Figure 3).

The spatial genetic structure was estimated by the coefficient of coancestria $\left(\mathrm{F}_{\mathrm{ij}}\right)$, and according to the results of the Sp statistic between the plants. In each population, different spatial distance classes ranging from 4 to 7 were estimated. According to the analysis of the correlograms, the spatial distribution pattern was observed between the random and aggregate populations with a non-significant positive coancestry value, that is, the individuals who are close to them have some degree of kinship, are genetically closer, and that there is a greater likelihood of inbreeding.

The results of the analyzes indicated a significant degree of kinship between the individuals of $S$. oleracea, demonstrating that spatial genetic structuring occurs, and suggests the presence of related individuals in the populations (Figure 3). This may be indicative of inbreeding in this population, which may lead to loss adaptability due to homozygosity. According to Griffin (1990), in general the homozygotes have a high proportion of deleterious recessive alleles, and can be extinguished since the heterozygotes have better performance.

The aggregate spatial distribution pattern was found in most populations in the first distance classes (1st and 2nd class), demonstrating that the spatial genetic structure (SGS) is the closest present to the mother plant. This result 
is different from that found in Vieira et al. (2015), which showed absence of SGS for Copernicia prunifera species. According to Defavari et al. (2009) several factors may induce a given population to present a significant spatial genetic structure, mainly the founding effect that is related to the presence of few genotypes in the population. Another important element is the genetic drift that due to limited seed dispersal can promote genetic structure.

Palm trees mainly present zoocoric dispersion syndrome (Zona \& Henderson, 1989). We observed in the populations collected that cattle consume the fruits of $S$. oleracea that fall from the palm tree. In addition, some birds, especially psittacines, collect fruits directly from the palm and consume them there or carry them to other areas, providing dispersion for long distances. Several studies suggest that seed accumulation under the parent plant may be indicative of defaunation and fragmentation (Wright et al., 2000; Wright \& Duber, 2001). Another issue is in relation to the density of these plants, in which many seedlings and fruits end up dying. Other works (Janzen, 1970) discuss the possibility of predation and herbivory attributes to vertebrates and insects, competition for substrates (nutrients) and light as well as the attack of pathogens such as microorganisms.
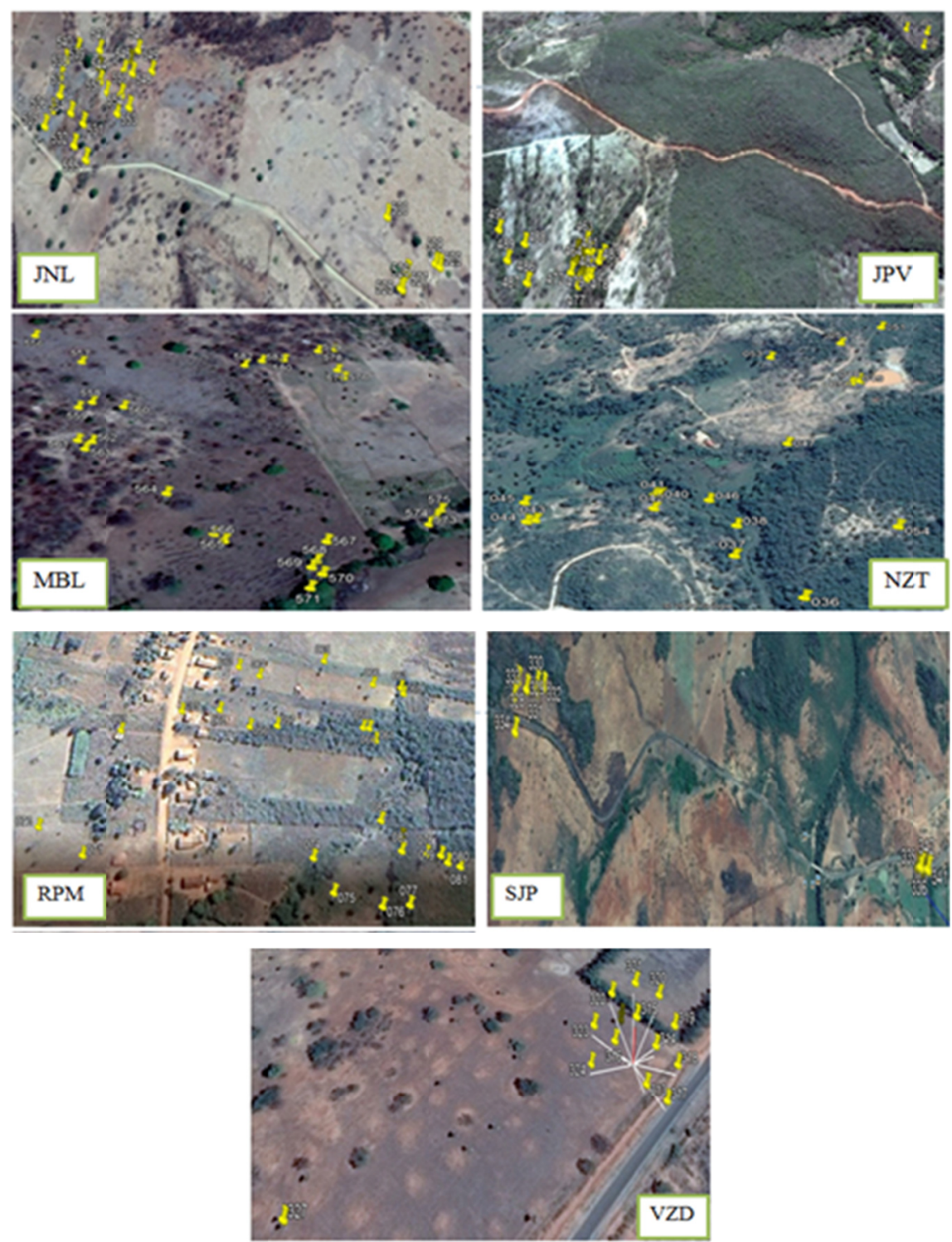

Figure 2. Satellite images with the position and spatial distribution of individuals sampled from Syagrus oleracea in the municipality of Japonvar, Josenópolis, Mirabela, Novorizonte, Rio Pardo de Minas, São João da Ponte and Varzelândia, MG

Source: Google Earth, 2018. 

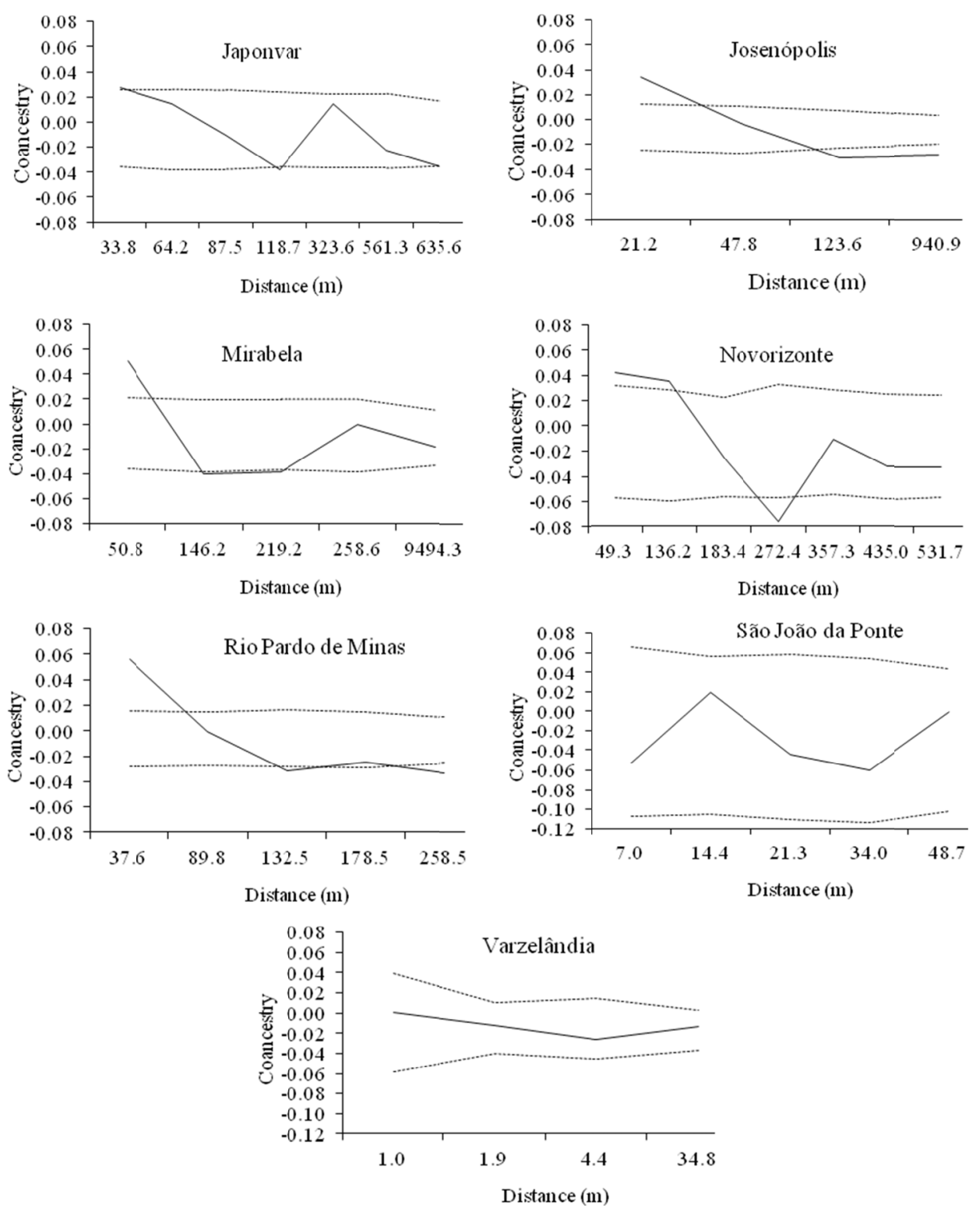

Figure 3. Correlations of kinship coefficient obtained by distance classes for individuals of Syagrus oleracea from the populations sampled in the municipality of Japonvar, Josenópolis, Mirabela, Novorizonte, Rio Pardo de Minas, São João da Ponte and Varzelândia

In the population of São João da Ponte and Varzelândia, a random distribution of individuals was observed, with a small variation in the values of the covensis coefficient between positive and negative throughout the classes, it is observed that in these populations the values of distance and of samples found are smaller than the others evaluated.

Therefore, the results indicate that the greatest spatial distribution found in this work is aggregated, which is also evidenced in several studies with natural populations of palm trees (Cabrera, 2007; Cappelatti, 2015; Matos, 2008; Oliveira, 2014).

\section{Conclusions}

The obtained indexes of genetic diversity indicated a high degree of kinship, and a reduction of the gene flow in the populations, possibly due to the existence of geographical barriers between the studied populations, which contribute to the occurrence of inbreeding. Aggregate pattern was observed in the genetic distribution, probably due to the inife of the dispersants. In addition, it was possible to conclude that ISSR markers proved to be efficient in estimating genetic diversity, and to identify polymorphism among individuals in the population. We 
propose that other studies should be carried out to enable the maintenance of genetic variability and the establishment of strategies for the conservation and sustainable use of the species Syagrus oleracea.

\section{Acknowledgements}

We thank the Biotechnology Postgraduate Program (PPGB) and the University of Montes Claros (UNIMONTES). The Minas Gerais State Agency for Research and Development-FAPEMIG (Fundação de Amparo à Pesquisa do Estado de Minas Gerais) for financing this study and research grants CRA-BIP-00067-17; CRA-BIP-00066-17; CRA-APQ-03101-16.

\section{References}

Brown, D. M., Brenneman, R. A., Koepfli, K. P., Pollinger, J. P., Mila, B., Georgiadis, N. J., ... Wayne, R. K. (2007). Extensive population genetic structure in the giraffe. BMC Biology, 5, 57. https://doi.org/10.1186/ 1741-7007-5-57

Cabrera, W. H., \& Wallace, R. (2007). Densidad y distribución espacial de palmeras arborescentes em un bosque preandino-amazónico de Bolivia. Ecología em Bolivia, 42(2).

Cappelatti, L., \& Schmitt, J. L. (2015). Distribuição espacial e estrutura populacional de Palmeiras (Arecaceae) em um fragmento de floresta ombrófila densa de terras baixas no sul do Brasil. Ciência Florestal, 25(4), 817-825. https://doi.org/10.5902/1980509820577

Carneiro, C. E. A., Holim, H. V. M., \& Fernandes, K. F. (2003). Procedimento eficiente na inibição do escurecimento de guariroba (Syagrus oleracea, Becc) durante processamento e armazenamento. Acta Sci. Agron., 25(2), 253-258. https://doi.org/10.4025/actasciagron.v25i2.1744

Defavari, G. R., Tarazi, R., Moreno, M. A., Ferraz, E. M., GAndara, F. B., \& Kageyama, P. Y. (2018). Estrutura genética espacial intrapopulacional de Hymenaea stigonocarpa Mart. Ex Hayne na Estação Ecológica de Itirapina, SP. Scientia Forestalis, 37(81), 89-9.

Demesure, B., Sodzi, N., \& Petit, R. J. (1995). A set of universal primers for amplification of polymorphic non-coding regions of mitochondrial and chloroplast DNA in plants. Molecular Ecology, 4, 129-131. https://doi.org/10.1111/j.1365-294X.1995.tb00201.x

Doyle, J. J., \& Doyle, J. L. (1987). A rapid DNA isolation procedure for small quantities of fresh leaf tissue. Phytochemical Bulletin, 19, 11-15.

Dutech, C., Maggia, L., Tardy, C., Joly, H. I., \& Jarne, P. (2003). Tracking a genetic signal of extinction-recolonization events in a neotropical tree species: Vouacapoua Americana Aublet in French Guiana. Evolution, 57(12), 2753-2764. https://doi.org/10.1554/03-184

Frankel, O. H. (1983). The place of management in conservation. In C. M. Schoenwald-Cox, S. M. Chamber, B. MacBryde, \& L. Thomas (Eds.), Genetics and Conservation (pp. 1-14). Benjamin-Cummings, London.

Griffin, A. R. (1990). Effects of inbreeding on growth of forest trees and implications for management of seed suplies for plantation programmes. In K. S. Bawa, \& M. Hadley (Eds.), Reprodutive ecology of tropical forest plants (pp. 355-374). Paris: UNESCO.

Hamrick, J. L., \& Godt, M. J. W. (1990). Allozyme diversity in plant species. In A. H. D. Brown, M. T. Clegg, A. L. Kahler, \& B. S. Weir (Eds.), Plant Population Genetics, Breeding and Genetic Resources (pp. 43-63). Sinauer, Sunderland, MA.

Hamrick, J. L., Godt, M. J. W., Murawski, D. A., \& Loveless, M. D. (1991). Correlação entre características de espécies e diversidade de aloenzimas: Implicações para a biologia da conservação. In D. A. Falk, \& K. E. Holsinger (Eds.), Genética e conservação de plantas raras (pp. 75-86), Oxford University Press, Nova Yor.

Hardy, O. J., Vekemans, X. (2002). SPAGeDi: A versatile computer program to analyse spatial genetic structure at the individual or population levels. Molecular Ecology Notes, 2, 618-620. https://doi.org/10.1046/j.14718286.2002.00305.x

Hardy, O. J. (2003). Estimation of pairwise relatedness between individuals and characterisation of isolation by distance processes using dominant genetic markers. Molecular Ecology, 12, 1577-1588. https://doi.org/ 10.1046/j.1365-294X.2003.01835.x

Hewitt, G. M. (1996). Some genetic consequences of ice ages, and their role in divergence and speciation. Biological Journal of the Linnean Society, 58, 247-276. https://doi.org/10.1006/bij1.1996.0035 
Hu, Y., Wang, L., Xie, X., Yang, J., Li, Y., \& Zhang, H. (2010). Genetic diversity of wild populations of Rheum tanguticum endemic to China as revealed by ISSR analysis. Biochemical Systematics and Ecology, 38(3), 264-274. https://doi.org/10.1016/j.bse.2010.01.006

Jaime, N. G. (2007). Aceitação do palmito de guariroba [Syagrus oleracea (Mart.) Becc.] em conservas sob diferentes ácidos orgânicos. Pesquisa Agropecuária Tropical, 37(4), 257-266.

Janzen, D. H. (1970). Herbivores and the number of tree species in tropical forests. American Naturalist, 104, 501-528. https://doi.org/10.1086/282687

Kamada, T., Picoli, E. A. T., Alfenas, A. C., Cruz, C. D., Vieira, R. F., \& Otoni, W. C. (2009). Diversidade genética de populações naturais de Pfaffia glomerata (Spreng.) Pedersen estimada por marcadores RAPD. Acta Scientiarum. Agronomy, 31(3), 403-409.

Kimura, M., \& Crow, J. F. (1964). The number of alleles that can be maintained in a finite population. Genetics, $49,725-738$.

Lewontin, R. C. (1972). The apportionment of human diversity. Evolutionary Biology, 6, 381-398.

Lorenzi, H. (1992). Árvores Brasileiras. Nova Odessa, Editora Plantarum.

Lorenzi, H. (2004). Palmeiras brasileiras e exóticas cultivadas. Nova Odessa, SP. Instituto Plantarum.

Martins, C. C., Nakagawa, J., \& Bovi, M. L. A. (1999). Tolerância à dessecação de sementes de palmito-vermelho (Euterpe espiritosantensis Fernandes). Revista Brasileira de Botânica, 22(3), 391-396. https://doi.org/10.1590/S0100-84041999000300007

Matos, D. M. S., \& Alves, L. F. (2008). Palm species distribution and soil moisture in a swampy area of the atlantic forest, South-Eastern Brazil. Ecotropica, 14, 69-74.

McDermott, J. M., \& McDonald, B. A. (1993). Gene flow in plant pathosystems. Annual Review of Phytopathology, 31, 353-373. https://doi.org/10.1146/annurev.py.31.090193.002033

Nei, M. (1973). Analysis of gene diversity in subdivided populations. Proc. Nat. Acad. Sci, 70, 3321-3323. https://doi.org/10.1073/pnas.70.12.3321

Nei, M. (1978). Estimation of average heterozygosity and genetic distance from a small number of individuals. Genetics, 89(3), 583-590.

Oliveira, K. F., Fisch, S. T. V., Duarte, J. S., Danelli, M. F., Martins, L. F. S., \& Joly, C. A. (2014). Estrutura e distribuição espacial de populações de palmeiras em diferentes altitudes na Serra do Mar, Ubatuba, São Paulo, Brasil. Rodriguésia, 65(4), 1043-1055. https://doi.org/10.1590/2175-7860201465414

Reis, E. F., Pinto, J. F. N., Assunção, H. F., \& Silva, D. F. P. (2017). Diversidade genética de frutos de macaúba de 35 municípios do estado de Goiás, Brasil. Pesq. Agropec. Bras., 52(4), 277-282. https://doi.org/10.1590/ s0100-204x2017000400008

Rohlf, F. J. (2000). Numerical taxonomy and multivariate analysis system, Version 2.11. Applied Biostatistics, New York.

Rossi, F. S., Rossi, A. A. B., Dardengo, J. F. E., Brauwers, L. R., Da Silva, M. L., \& Sebbenn, A. M. (2014). Diversidade genética em populações naturais de Mauritia flexuosa L. f. (Arecaceae) com uso de marcadores ISSR. Sci. For, 42(104), 631-639.

Salimath, S. S., Oliveira, A. C., Godwin, I. D., \& Bennetzen, J. L. (1995). Assessment of genome origins and genetic diversity in the genus Eleusine with DNA markers. Genome, 38, 757-763. https://doi.org/10. 1139/g95-096

Santelli, P., Calbo, M. E. R., \& Calbo, A. G. (2006). Fisiologia pós-colheita de frutos da palmeira Syagrus oleracea (Mart.) Becc. (Arecaceae). Acta Botânica Brasilica, 20(3), 523-528. https://doi.org/10.1590/ S0102-33062006000300003

Schaal, B. A., Hayworth, D. A., Olsen, K. M., Rauscher, J. T., \& Smith, W. A. (1998). Phylogeographic studies in plants: problems and prospects. Molecular Ecology, 7, 465-474. https://doi.org/10.1046/j.1365-294x.1998. 00318.x

Shimokomaki, M. (1975). Estudo comparativo entre os palmitos de sabor doce (palmito-juçara-Euterpe edulis Mart. e açaí-Euterpe oleracea Mart.) e de Sabor Amargo (guariroba-Syagrus oleracea Becc.). 1 Composição química, péptides e aminoácidos livres. Coletânea do Ital., 6, 69-80. 
Silva, S. M. M. (2014). Parâmetros genéticos para a conservação de Hymenaea courbaril L. Na Amazônia Sul-Ocidental. $C$ i. Fl., 24(1).

Vieira, F. de A. (2015). Diversidade genética de Copernicia prunifera com o uso de marcadores moleculares ISSR. Rev. Bras. Ciênc. Agrár. Recife, 10(4), 525-531. https://doi.org/10.5039/agraria.v10i4a5040

Wright, S. J., \& Duber, H. C. (2001). Poachers and forest fragmentation alter seed dispersal, seed survival, and seedling recruitment in the palm Attalea butyraceae, with implications for tropical tree diversity. Biotropica, 33, 583-595. https://doi.org/10.1646/0006-3606(2001)033[0583:PAFFAS]2.0.CO;2

Wright, S. J., Zeballos, H., Domínguez, I., Gallardo, M. M., Moreno, M. C., \& Ibañez, R. (2000). Poachers alter mammal abundance, seed dispersal, and seed predation in a neotropical forest. Conservation Biology, 14, 227-239. https://doi.org/10.1046/j.1523-1739.2000.98333.x

Yeh, F. C., Yang, R. C., \& Boyle, T. (1999). POPGENE: Microsoft Windows-based freeware for population genetic analysis, Version 1.31. University of Alberta, Canada and Centre for International Forestry Research, Canadá.

Zona, S., \& Henderson, A. (1989). A review of animal-mediated seed dispersal of palms. Selbyana, 11, 6-21.

\section{Copyrights}

Copyright for this article is retained by the author(s), with first publication rights granted to the journal.

This is an open-access article distributed under the terms and conditions of the Creative Commons Attribution license (http://creativecommons.org/licenses/by/4.0/). 